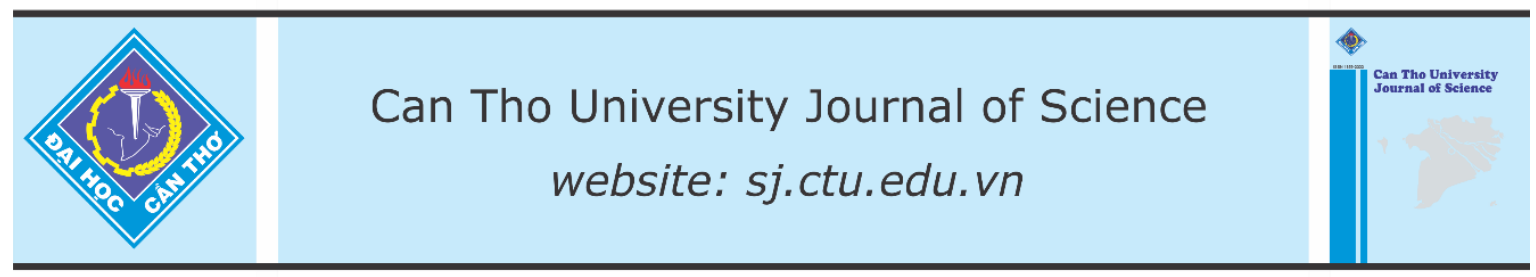

DOI: $10.22144 /$ ctu.jen.2021.013

\title{
Survey on the roles and impacts of seaweeds and aquatic plants in the improved extensive black tiger shrimp farms in Bac Lieu province
}

\author{
Nguyen Thi Ngoc Anh ${ }^{1 *}$, Nguyen Hoang Vinh ${ }^{1,2}$, Lam My Lan ${ }^{1}$ and Tran Ngoc Hai ${ }^{1}$ \\ ${ }^{1}$ College of Aquaculture and Fisheries, Can Tho University, Viet Nam \\ ${ }^{2}$ Bac Lieu Agriculture Extension Center, Viet Nam \\ *Correspondence: Nguyen Thi Ngoc Anh (email: ntnanh@ctu.edu.vn)
}

\section{Article info.}

Received 22 Feb 2021

Revised 12 May 2021

Accepted 04 Jun 2021

\section{Keywords}

Aquatic plant, improved extensive farm, production, red seaweed, shrimp

\begin{abstract}
A survey was conducted to assess the roles and impacts of seaweeds and aquatic plants on the production and financial efficiency of black tiger shrimp in improved extensive farms through direct interviews with 60 farmers from Dong Hai district, Bac Lieu province. The householders were divided into two groups based on the presence of natural seaweed and aquatic plant, including group 1: the presence of different seaweeds and aquatic plants but the absence of red seaweed (mixed vegetation) and group 2: the presence of red seaweed dominates over the mixed vegetation. The surveyed results showed that group 2 had an average shrimp yield of $268.6 \mathrm{~kg} / \mathrm{ha} /$ year with a profit of 58.4 million VND/ha/year, which was higher than that of group 1 (shrimp yield of $203.1 \mathrm{~kg} / \mathrm{ha} / \mathrm{year}$ and profit of 43.0 million VND/ha/year). Almost all farmers agreed that seaweeds and aquatic plants acted as important roles in improving water quality, providing natural food and shelter for shrimp, crab, and fish. Farmers, on the other hand, claimed that their excessive growth (high biomass) increased water transparency, limited living space, and hampered the activities of shrimp, crab, and other organisms, as well as reduced shrimp growth and production and polluted water after seaweed died off. Notably, the farm that maintained vegetation coverage $\leq 50 \%$ obtained higher shrimp production and profit than pond with coverage $>50 \%$. Moreover, $46.7 \%$ of farmers preferred red seaweed over other seaweed and aquatic plant species in their farms.
\end{abstract}

\section{INTRODUCTION}

Shrimp sector is one of the largest aquaculture industries in Vietnam with two main cultured species i.e. black tiger shrimp (Penaeus monodon) and white leg shrimp (Litopenaeus vannamei). According to Ministry of Agriculture and Rural Development (2017), a total area of shrimp farming in the Mekong Delta (MD) of Vietnam was over 600,000 ha in year 2017, mainly in Ca Mau, Bac Lieu, Soc Trang, Kien Giang, Ben Tre and Tra Vinh provinces. Within these places, the improved extensive shrimp farming was approximately estimated around 337,000 ha. Bac Lieu province located in the south-western Mekong Delta had an aquaculture water area of 138,174 ha with dominance in the improved extensive shrimp farming.

For long time, the improved extensive shrimp farming system provided an important livelihood for many small-scale farmers in the MD, the shrimp was stocked a low stocking density and relied on natural 
food (Brennan et al., 2000; Nhuong et al., 2002; Tho et al., 2012). The improved extensive shrimp farming system was a polyculture system that reared shrimp postlarvae and mud crablet were stocked as wild shrimp, wild fish and wild crabs were also existed (Nhuong et al., 2002; Tho et al., 2012; Hai et al., 2016). Notably, seaweeds (Enteromorpha, Chaetomorpha, Cladophora, and Gracilaria) and aquatic plants (Najas sp. and Typha species) developed naturally on the platform (shallow part of the improved extensive shrimp farming). They were beneficial for the environment, particularly to create ideal habitat for shrimp, crab and fish in the pond (Hai et al., 2016). Other findings found that aquatic macrophytes and seaweeds played important roles in marine and brackish ecosystems as they could modify the physico-chemical conditions in water bodies. For example, macrophytes and seaweeds form structural habitats for epiphytes and fauna, trap detritus, provide oxygen, shelter for aquatic organisms. They also served as an important food source for aquatic animals, providing both living (grazing food webs) and dead organic matter (detritus food webs) in the water bodies (Hurd et al., 2014; Jaikumar et al., 2011; Thomas \& da Cunha, 2010). However, different aquatic plant and seaweed species act different functions; especially their excessive development could cause negative impacts to water bodies (O'Hare et al., 2018; Thomas \& da Cunha, 2010). Therefore, the purpose of this investigation was to assess the role of seaweeds and aquatic plants, which naturally occur in the improved extensive shrimp pond and their effects on the productivity and financial efficiency of the farming system in Bac Lieu province. These results could provide useful information for appropriate management of seaweeds and aquatic plants, contributing to the development of a sustainable shrimp farming system in the region.

\section{METHODOLOGY}

\subsection{Study area}

The study was performed by interviewing farmers who culturing the black tiger shrimp in the improved extensive farms (IEF) from Dong Hai district, Bac Lieu province, from September to November 2019. Sixty selected farmers were divided into two groups based on the existence status of seaweeds and aquatic plants in their farms. Group 1 (30 farmers) has the IEF with natural occurrences of various seaweeds and aquatic plants but absence of red seaweed Gracilaria (mixed vegetation). Group 2 (30 farmers) has the IEF with a natural occurrence of red seaweed Gracilaria, which dominates over the mixed vegetation.

\subsection{Data collection}

The questionnaires contained a series of multiple choice and open-ended questions about technical aspects, the roles, and impacts of seaweeds and aquatic plants in the IEF. Questions were interpreted in an alternative way to validate that farmers understood the questions. Detailed information in the questionnaires included (1) pond design characteristics (pond size, peripheral ditch, ratio of ditch and platform, water level from platform, water depth in the ditch), and technical aspects (pond preparation, chemical use, pond management, stocking density, harvesting, etc.). (2) Financial aspects include production costs, income, selling price of product and profit. (3) Information related to farmers' perceptions on the role and impact of seaweed and aquatic plants in shrimp ponds, the season of appearance, management methods and desired species of seaweed to be maintained in the pond.

\subsection{Data analysis}

Data from the questionnaires were coded and entered a Microsoft Excel spreadsheet for statistical analysis, which primarily involved simple descriptive statistics. The results of multiple-choice questions were tested for differences in frequency and Student's t-test was applied to identify significant differences between two groups at a significance level of $\mathrm{p}<0.05$. All statistics were performed using SPSS for Windows version 16.0

\section{RESULTS AND DISCUSSION}

\subsection{Information on technical and financial aspects}

The technical parameters and financial efficiency of improved-extensive shrimp farms in Bac Lieu are shown in Table 1.

Pond structure: the pond area ranged from 0.7 to 5.0 ha with a mean of $2.0 \mathrm{ha} /$ household. The peripheral ditch widths were between 1.5-4.0 m, corresponding to the ditch ratio of $15-30 \%$ and the platform of $70-85 \%$ of the total pond area. The water levels from the ditch and from the platform (shallow part) varied in the ranges of $0.8-2.0 \mathrm{~m}, 0.3-0.8 \mathrm{~m}$, respectively. According to Tho et al. (2012), the area of the improved-extensive shrimp ponds in the MD provinces ranged from 1-2 ha, and the appropriate ditch proportions are $25-30 \%$ and the water level on the platform should be higher than $50 \mathrm{~cm}$. This technique is to minimize adverse effects from large 
fluctuation of temperature and to limit light penetration to the pond bottom during daytime.

Pond preparation: the surveyed farmers perform pond preparation 1-2 times/year and the majority of them $(60-70 \%)$ do not use chemicals, other farmers use zeolite/lime (10-20\%) or inorganic fertilizer (3$8 \%)$ and debris roots (15-20\%) during pond preparation.

Stocking technique: all the interviewed famers said that they applied polyculture of black tiger shrimp and mud crabs to enhance production efficiency and increase their income. In this system, farmers harvested partially shrimp, crab while shrimp postlarvae (PL) and crablet were still stocked many

times. The black tiger shrimp was the main culture species. Shrimp PL 12-15 were stocked from 4 to 18 times/year at densities of $2-7 \mathrm{ind} / \mathrm{m}^{2} /$ time, while crabs was reared about 3-8 times/year at the density of $0.05-0.33 / \mathrm{m}^{2} /$ time. The size of crabs is greatly different among farmers depending on their conditions and time of culture. Small crablets (instar 1-2 stage) were from commercial hatcheries while juveniles of 1-10 $\mathrm{g}$ were from the wild. The improvedextensive shrimp farming characterized by polyculture system with low stocking density (1-5 ind $\left./ \mathrm{m}^{2}\right)$, and usually does not exceed $7 \mathrm{ind} / \mathrm{m}^{2}$ for shrimp, and $0.05-0.10 \mathrm{ind} / \mathrm{m}^{2}$ for crab (Hai et al., 2016; Tho et al., 2012).

Table 1. General information on technical aspects and financial efficiency from the improved extensive shrimp farms of 60 surveyed farmers in Bac Lieu province

\begin{tabular}{|c|c|c|}
\hline Description & Means \pm SD $(n=60)$ & Min-Max \\
\hline \multicolumn{3}{|l|}{ Pond structure } \\
\hline Pond area (ha) & $2.0 \pm 1.1$ & $0.9-4.8$ \\
\hline Peripheral ditch width (m) & $2.6 \pm 0.8$ & $1.5-4.0$ \\
\hline Ditch ratio $(\%)$ & $24.4 \pm 5.1$ & $15-30$ \\
\hline Platform ratio $(\%)$ & $75.6 \pm 5.1$ & $70-85$ \\
\hline Water level in the ditch $(\mathrm{m})$ & $1.1 \pm 0.3$ & $1.1-2.0$ \\
\hline Water level in the platform $(\mathrm{m})$ & $0.5 \pm 0.1$ & $0.3-0.8$ \\
\hline \multicolumn{3}{|l|}{ Technical parameters } \\
\hline Pond preparation (time/year) & $1.3 \pm 0.4$ & $1-2$ \\
\hline \multicolumn{3}{|c|}{ Chemical used during pond preparation (\% of farmer) } \\
\hline - Zeolite/lime & $15.0 \pm 5.0$ & $10-20$ \\
\hline - Inorganic fertilizers: NPK, DAP & $5.0 \pm 1.7$ & $3-8$ \\
\hline - Debris roots & $16.7 \pm 3.3$ & $15-20$ \\
\hline - Not utilization & $61.7 \pm 8.4$ & $60-70$ \\
\hline Shrimp stocking density (ind $/ \mathrm{m}^{2} /$ batch) & $3.8 \pm 1.6$ & $2-7$ \\
\hline Crab stocking density (ind $/ \mathrm{m}^{2} /$ batch) & $0.15 \pm 0.06$ & $0.05-0.33$ \\
\hline Shrimp stocking (time/year) & $9.4 \pm 3.2$ & 4-18 \\
\hline Crab stocking (time/year) & $6.4 \pm 3.2$ & $3-12$ \\
\hline Water exchange (time/month) & $2.0 \pm 0.2$ & $2-3$ \\
\hline Water exchange rate (\%/time) & $41.5 \pm 15$ & $20-70$ \\
\hline First harvested shrimp after stocking (month) & $3.7 \pm 0.6$ & $3-4$ \\
\hline Shrimp size at harvest $(\mathrm{g})$ & $38.9 \pm 7.9$ & $25-62$ \\
\hline \multicolumn{3}{|l|}{ Yields of harvested products $(\mathrm{kg} / \mathrm{ha} /$ year $)$} \\
\hline Black tiger shrimp & $235.9 \pm 109.5$ & $62.5-483.3$ \\
\hline Mud crab & $91.1 \pm 72.5$ & $13.3-440$ \\
\hline Wild shrimp & $37.9 \pm 21.8$ & 13-125 \\
\hline \multicolumn{3}{|l|}{ Financial efficiency (million VND/ha/year) } \\
\hline Fixed cost & $2.7 \pm 1.6$ & $0.8-6$ \\
\hline Variable cost & $11.8 \pm 3$ & $5-21$ \\
\hline Total production cost & $14.5 \pm 3.4$ & $8-23$ \\
\hline Total income & $65.2 \pm 32.5$ & $20.2-164.7$ \\
\hline Profit & $50.7 \pm 31.4$ & 6.1-148.7 \\
\hline Cost benefit (time) & $3.6 \pm 2.1$ & 0.4-9.7 \\
\hline
\end{tabular}


Pond management: water exchange was mainly done during spring tide to ensure good water quality, provided natural food, wild shrimp and wild fish in the pond as well as reduce salinity in the culture pond in the dry season. The new water source was taken directly from the canal based on the spring tide (2 times/month) using sluice gate. The average water exchange took place 3-5 days/time at rate of 20 and $70 \%$ water volume. In addition, the water exchange in spring tide period was to stimulate shrimp movement to the trap net for partial harvesting big sized shrimps.

Yield: the surveyed results showed that yield varied greatly among the farms. Black tiger shrimp yield was from $62.5-483.3 \mathrm{~kg} / \mathrm{ha} /$ year with a mean of $235.9 \mathrm{~kg} / \mathrm{ha} / \mathrm{year}$. Mud crab yielded between 13.3 and $440 \mathrm{~kg} / \mathrm{ha} /$ year (average of $91.1 \mathrm{~kg} / \mathrm{ha} /$ year) and wild shrimp was from 13 to $125 \mathrm{~kg} / \mathrm{ha} /$ year (average of $37.9 \mathrm{~kg} / \mathrm{ha} /$ year).

Financial efficiency: the total production cost in the improved extensive shrimp pond was relatively low, ranging from 8-23 million VND/ha/year with an average of 14.5 million VND/ha/year), and total income achieved from 20.2-164.7 million VND/ha/year with an average of 65.2 million VND/ha/year. The profit varied from 6.1-148.7 million $\mathrm{VND} / \mathrm{ha} /$ year (average of 50.7 million $\mathrm{VND} /$ ha/year) corresponding to the cost benefit ratios of 0.4-9.7 times (average of 3.6 times). The large variation in production and financial efficiency among farmers could be due to influenced by the pond management, climate change (Mai et al., 2016; Son et al., 2018; Tho et al., 2012) and the development of seaweed and aquatic plants in the improved extensive shrimp ponds (Anh et al., 2017; Hai et al., 2016; Son et al., 2018).

\subsection{Effects of seaweeds and aquatic plants in the improved extensive shrimp farm}

\subsubsection{Effects of mixed vegetation and red seaweed on shrimp production and financial efficiency in the improved extensive shrimp pond}

The effects of natural occurrence of mixed vegetation and red seaweed in the improved extensive shrimp pond on yield and financial efficiency are presented in Table 2 .

Table 2. Comparing production of harvested products and financial efficiency between two groups of vegetation

\begin{tabular}{|c|c|c|}
\hline Description & $\begin{array}{c}\text { Mixed vegetation } \\
(\text { group } 1, n=30)\end{array}$ & $\begin{array}{c}\text { Red seaweed } \\
(\text { group } 2, n=30)\end{array}$ \\
\hline \multicolumn{3}{|l|}{ Production of harvested products (kg/ha/year) } \\
\hline Black tiger shrimp & $203.1 \pm 108.8^{\mathrm{a}}$ & $268.6 \pm 106.7^{b}$ \\
\hline Mud crab & $101.9 \pm 95.2^{\mathrm{a}}$ & $80.2 \pm 37.3^{\mathrm{a}}$ \\
\hline Wild shrimp & $31.9 \pm 22.5^{\mathrm{a}}$ & $39.5 \pm 25.3^{\mathrm{a}}$ \\
\hline Size of black tiger shrimp at harvest $(\mathrm{g})$ & $36.8 \pm 6.9^{\mathrm{a}}$ & $41.0 \pm 8.3^{\mathrm{b}}$ \\
\hline \multicolumn{3}{|l|}{ Selling price (thousand VND/kg) } \\
\hline Black tiger shrimp & $177.7 \pm 33.5^{\mathrm{a}}$ & $198.3 \pm 32.4^{\mathrm{b}}$ \\
\hline Mud crab & $172.3 \pm 40^{\mathrm{a}}$ & $194.8 \pm 48.6^{\mathrm{a}}$ \\
\hline Wild shrimp & $72.8 \pm 12.2^{\mathrm{a}}$ & $72.3 \pm 16.1^{\mathrm{a}}$ \\
\hline \multicolumn{3}{|l|}{ Financial efficiency (million VND/ha/year) } \\
\hline Fixed cost & $2.8 \pm 1.7^{\mathrm{a}}$ & $2.6 \pm 1.4^{\mathrm{a}}$ \\
\hline Variable cost & $12.5 \pm 2.3^{\mathrm{a}}$ & $11.1 \pm 3.5^{\mathrm{a}}$ \\
\hline Total production cost & $15.3 \pm 3.2^{\mathrm{a}}$ & $13.7 \pm 3.6^{\mathrm{a}}$ \\
\hline Total income & $58.2 \pm 35.5^{\mathrm{a}}$ & $72.1 \pm 28.1^{\mathrm{a}}$ \\
\hline Profit & $43.0 \pm 34.6^{\mathrm{a}}$ & $58.4 \pm 26.3^{\mathrm{a}}$ \\
\hline Cost benefit ratio (time) & $2.8 \pm 2.1^{\mathrm{a}}$ & $4.3 \pm 1.9^{\mathrm{b}}$ \\
\hline
\end{tabular}

Mean $\pm S D$, values within the same row sharing different superscripts are significantly different $(p<0.05)$

The shrimp pond with the presence of mixed vegetation (group 1) achieved the average tiger shrimp yield of $203.1 \mathrm{~kg} / \mathrm{ha} /$ year, which was significantly lower $(\mathrm{p}<0.05)$ than group 2 with the presence of red seaweed $(268.6 \mathrm{~kg} / \mathrm{ha} /$ year $)$. The production of mud crabs was no statistical difference between two groups ( $p>0.05)$ with average values of 101.9 and $80.2 \mathrm{~kg} / \mathrm{ha} /$ year for group 1 and 2 , respectively. The mean yield of wild shrimp varied from 31.9-39.5 $\mathrm{kg} / \mathrm{ha} /$ year. 
The harvested size of tiger shrimp and selling price were from 36.8-41.0 $\mathrm{g}$ and 177.7-198.3 thousand $\mathrm{VND} / \mathrm{kg}$, respectively, of which group 1 had significantly lower values $(p<0.05)$ than group 2 . Selling price of crab and wild shrimp of two groups were similar, and varied in the ranges of 172.3-194.8 and 72.3-72.8 thousand VND/kg, respectively.

The total production cost between the two groups did not differ much, averaging 13.7-15.3 million VND/ha/year. Total income and profits in group 2 were on average of 72.1 and 58.4 million $\mathrm{VND} /$ ha/year, respectively which were higher than that of group 1 (58.2 and 43.0 million VND/ha/year) but the difference was not significant ( $p>0.05)$. The average cost benefit ratio in group 2 (4.3 times) was significantly higher than that of group 1 (2.8 times). These results showed that group 2 (natural occurrence of red seaweed in the culture pond) resulted in lower production cost, higher income and profit than that of group 2 (natural presence of mixed vegetation in the culture pond). Additionally, the bigger size of harvested tiger shrimp and the higher selling price in group 2 gave higher financial efficiency.

\subsubsection{Effects of vegetation coverage percentage on shrimp production and profit of farmers}

Surveyed results showed that the vegetation coverage percentage (the percentage of seaweed and aquatic plant areas/total pond area) in the improved extensive shrimp ponds had a great impact on the productivity and profitability of farmers. The average shrimp production in the $\leq 50 \%$ coverage obtained average of $346.9 \mathrm{~kg} / \mathrm{ha} / \mathrm{year}$, which was significantly higher $(\mathrm{p}<0.05)$ than in ponds with $>50 \%$ coverage $(206.2 \mathrm{~kg} / \mathrm{ha} /$ year). Similarly, the crab production at coverage of $\leq 50 \%(104.7 \mathrm{~kg} / \mathrm{ha} /$ year $)$ was higher than in the coverage $>50 \%$ group $(78.4$ $\mathrm{kg} / \mathrm{ha} /$ year) but there was no statistical difference (p>0.05). Production of wild shrimp between the two coverage groups was similar, yielding average of $35.2-36.1 \mathrm{~kg} / \mathrm{ha} / \mathrm{year}$. Moreover, total income, profit and cost benefit ratio in the group of $\leq 50 \%$ coverage averaged 75.6 and 60.6 million $\mathrm{VND} / \mathrm{ha} / \mathrm{year}$ and 4.2 times, respectively, which were significantly higher $(\mathrm{p}<0.05)$ compared to those in the group of $>50 \%$ coverage (55.4 and $41.4 \mathrm{million} / \mathrm{ha} / \mathrm{year}$ and 3.1 times), respectively (Table 3).

Table 3. Production and profit according to coverage percentage of seaweeds and aquatic plants present in the improved extensive shrimp pond

\begin{tabular}{lrr}
\hline Coverage ratio & $\begin{array}{r}\text { Coverage ratio } \leq \mathbf{5 0 \%} \\
(\mathbf{n}=\mathbf{3 9})\end{array}$ & $\begin{array}{r}\text { Coverage ratio }>\mathbf{5 0 \%} \\
(\mathbf{n}=\mathbf{2 1})\end{array}$ \\
\hline Production (kg/ha/year) & & \\
\hline - Black tiger shrimp & $267.6 \pm 118.9^{\mathrm{b}}$ & $206.2 \pm 92.1^{\mathrm{a}}$ \\
- Mud crab & $104.7 \pm 91.3^{\mathrm{a}}$ & $78.4 \pm 47.1^{\mathrm{a}}$ \\
- Wild shrimp & $35.2 \pm 24^{\mathrm{a}}$ & $36.1 \pm 24.5^{\mathrm{a}}$ \\
Total income (million/ha/year) & $75.6 \pm 36.1^{\mathrm{b}}$ & $55.4 \pm 25.6^{\mathrm{a}}$ \\
Profit (million/ha/year) & $60.6 \pm 34.9^{\mathrm{b}}$ & $41.4 \pm 24.9^{\mathrm{a}}$ \\
Cost benefit ratio (time) & $4.2 \pm 2.5^{\mathrm{b}}$ & $3.1 \pm 1.6^{\mathrm{a}}$ \\
\hline
\end{tabular}

Mean $\pm S D$, values within the same row sharing different superscripts are significantly different $(p<0.05)$

Previous studies have found that seaweeds and aquatic plants serve as shelter and natural food source for shrimp, crabs, and fish in the improved extensive shrimp pond. However, if the percentage of vegetation coverage is very high, it may reduce the development of benthic organisms, limit light penetration, and compete for nutrients with phytoplankton, potentially leading to natural food shortage in the culture pond. Additionally, high vegetation coverage might result in a lack of oxygen at night, reducing shrimp survival. These negative effects could cause reduction of productivity of shrimp in the culture ponds and income of farmers (Anh et al., 2017; Hai et al., 2016; Son et al., 2018).

\subsection{Farmers' perception about natural occurrence of seaweeds and aquatic plants in the improved extensive shrimp ponds}

\subsubsection{Farmers' opinions about seaweeds and aquatic plants}

The surveyed farmers reported that there are four types of seaweeds and three types of aquatic plants either co-occurrence at the same time or successive development in the improved extensive shrimp ponds. Of the four types of seaweed, $83.3 \%$ of farmers found that green seaweed (blanket seaweed) belonging to the Cladophoraceae family is mostly found all year round, followed by Gracilaria $(50 \%$ of households), and Enteromorpha (35\% of 
households) and Spirogyra (18.3\% of households). Three types of aquatic plants including stone algae Najas (33.3\% of households), Ceratophyllum (8.3\% of households), and Eleocharis (51.7\%) were naturally present in shrimp ponds (Table 4).

Table 4. Farmers' opinions about seaweeds and aquatic plants naturally present in the improved extensive shrimp ponds $(\mathrm{n}=60)$

\begin{tabular}{|c|c|c|c|c|c|c|c|}
\hline \multirow{3}{*}{ Type of vegetation } & \multicolumn{4}{|c|}{ Seaweed } & \multicolumn{3}{|c|}{ Aquatic plant } \\
\hline & \multirow{2}{*}{$\begin{array}{r}\begin{array}{c}\text { Clado- } \\
\text { phoraceae }\end{array} \\
\text { (Rong } \\
\text { mền) } \\
\end{array}$} & \multirow{2}{*}{$\begin{array}{l}\text { Gracilaria } \\
\text { (Rong câu) } \\
\end{array}$} & \multirow{2}{*}{$\begin{array}{r}\text { Enteromorpha } \\
\text { (Rong bún) }\end{array}$} & \multirow{2}{*}{$\begin{array}{r}\text { Spirogyra } \\
\text { (Rong } \\
\text { nhớt) }\end{array}$} & \multirow{2}{*}{$\begin{array}{r}\text { Najas } \\
\begin{array}{r}\text { Rong } \\
\text { đá) }\end{array} \\
\end{array}$} & \multicolumn{2}{|c|}{ Ceratophyllum Eleocharis } \\
\hline & & & & & & $\begin{array}{r}\text { (Rong đuôi } \\
\text { chồn) }\end{array}$ & (Cỏ năn) \\
\hline $\begin{array}{l}\text { Farmer opinion } \\
(\%)^{*}\end{array}$ & 83.3 & 50.0 & 35.0 & 18.3 & 33.3 & 8.3 & 51.7 \\
\hline \multicolumn{8}{|c|}{ Environmental conditions } \\
\hline Salinity (\%o) & $15-35$ & $10-25$ & $15-25$ & $2-10$ & $1-10$ & $1-10$ & $2-10$ \\
\hline $\begin{array}{l}\text { Water level in plat- } \\
\text { form }(\mathrm{cm})\end{array}$ & $5-40$ & $20-50$ & $15-40$ & $20-50$ & $20-50$ & $20-50$ & $40-60$ \\
\hline Transparency $(\mathrm{cm})$ & 40-60 & $30-50$ & $30-50$ & $40-50$ & $40-60$ & $40-60$ & $40-60$ \\
\hline \multicolumn{8}{|c|}{ Duration (month) seaweeds and aquatic plants well develop (\% of farmer opinion) } \\
\hline Mar-Sept & 78.3 & & & & & & \\
\hline $\begin{array}{l}\text { Jun-Oct } \\
\text { Oct-Feb }\end{array}$ & & 48.1 & 54.7 & 28.3 & 32.1 & 35.4 & 52.5 \\
\hline \multicolumn{8}{|c|}{ Types of seaweed and aquatic plants naturally develop in the improve extensive shrimp pond (\% of farmer idea) } \\
\hline Farmer idea $(\%)$ & & $\begin{array}{r}\text { Having } 2 \\
\text { weed/aq }\end{array}$ & $\begin{array}{l}\text { types of sea- } \\
\text { quatic plants } \\
41.7\end{array}$ & $\begin{array}{r}\text { Having } 3 \text { type } \\
\text { weed/aquatic } \\
50.0\end{array}$ & $\begin{array}{l}\text { S of sea- } \\
\text { plants }\end{array}$ & $\begin{array}{r}\text { Having } 4 \text { typ } \\
\text { weed/aquati } \\
8.3\end{array}$ & $\begin{array}{l}\text { es of sea- } \\
\text { c plants }\end{array}$ \\
\hline
\end{tabular}

* Farmer opinion about seaweed and aquatic plants naturally develop in the improved extensive shrimp pond

Furthermore, $41.7 \%$ of farmers noticed that there were 2 types of seaweed/aquatic plants in shrimp ponds, $50 \%$ of households saw 3 types of seaweed/aquatic plants and $8.3 \%$ of households said that there are usually 4 types seaweeds/aquatic plants. These farmers found that seaweeds and aquatic plants were present and developed at the same time or appeared alternately during the year such as green seaweed with viscous algae, aquatic plant (stone weed), green seaweed with red seaweed, green seaweed with stone weed and vegetation, etc. Similarly, Anh (2015) and ITB-Vietnam (2011) reported that seaweed and aquatic plants appear simultaneously or they grow alternately and successively in brackish water bodies.

From the surveyed results, $78.3 \%$ of farmer found that green seaweed (Cladophoraceae) grows well in shrimp pond from March to September with suitable salinity and water level ranges of 15-35\%o and 5-40 $\mathrm{cm}$, respectively. Red seaweed (Gracilaria) and gut weed (Enteromorpha) well develop from October to February next year at salinities of 10-25\%o and water depth of 20-50 cm for Gracilaria (48.1\% of farmer), and at salinities of $15-25 \%$ and water levels of $15-$ $40 \mathrm{~cm}$ for Enteromorpha (54.7\% of farmers). Other farmers reported that viscous algae Spirogyra
(28.3\% of farmers), stone seaweed Najas (32.1\% of farmers), weasel-tail weed Ceratophyllum (35.4\% of farmers) and tube-grass Eleocharis (52.5\% of farmers). They most appear in shrimp pond from June to October (rainy season) with salinity range of $1-10 \%$ and water levels of $20-50 \mathrm{~cm}$, particularly Eleocharis grows best at $40-60 \mathrm{~cm}$. The suitable transparency for the development of seaweeds and aquatic plants are from $30 \mathrm{~cm}$ onwards.

Previous studies reported that the growth and distribution of seaweed and aquatic plants were influenced by environmental factors such as light intensity, salinity, temperature, turbidity and nutrients in their habitat. Temperature and salinity are the two main factors affecting the growth, reproduction, morphology, distribution, community structure, and each species have optimal salinity and temperature ranges for growth and development (Hurd et al., 2014; O'Hare et al., 2018; Thakur et al., 2008; Vaheeda \& Thara, 2014). Similarly, Anh (2015) conducted monthly observations of seaweeds and aquatic plants in the improved extensive farms and other brackish water bodies in Bac Lieu and Soc Trang provinces for one year. Author found that natural productivity of green seaweeds (gut weed, Enteromorpha spp. and genus belonging to 
Cladophoraceae) and aquatic plants (Najas spp.) greatly fluctuated among the water bodies, and their development was highly affected by abiotic and biotic factors. These factors are geography, environmental conditions (temperature, salinity, turbidity, depth, etc.), nutrient availability, and structure/characteristics of water bodies, dominant species, and farming management. Temperature and salinity are the critical factors affecting seaweed development and their productivity. Both gut weed and Cladophoraceae often coexisted and dominated over aquatic plant, Najas spp. Besides, Enteromorpha spp. was found at a certain time of the year where temperatures were less than $35^{\circ} \mathrm{C}$. Green seaweeds Cladophoraceae family (Cladophora, Chaetomorpha and Rhizoclonium) were observed year round and Najas spp. commonly occurred at low salinities
$(0-10 \%)$ in the rainy season (from June to November).

\subsubsection{Farmers' perception about the roles and impacts of seaweeds and aquatic plants in shrimp ponds}

The roles of seaweed and aquatic plant: majority of farmers stated that seaweed and aquatic plants help improve water quality in culture ponds $(68.3 \%)$, serve as direct food $(61.7 \%)$, and provide shelters $(65.0 \%)$ and natural food for fish, shrimp and crab (48.3\%). In addition, a few farmers $(6.7 \%)$ use seaweed and aquatic plants as supplementary food for livestock such as pigs, chickens, and ducks (Table 5).

Table 5. The role, impact, and management of seaweed and aquatic plants in the improved extensive shrimp ponds

\section{Role}

Farmer ideas $(\%)$

2. Impact

Farmer ideas $(\%)$

\section{Control methods}

Farmer ideas $(\%)$

\section{Water quality} improvement

68.3

Very clear water 50.0 Good pond preparation+

high water depth +suitable turbidity

$\begin{array}{cc}\text { Direct food for } & \text { Shelter for } \\ \text { shrimp, crab, } & \text { shrimp, crab, } \\ \text { fish } & \text { fish } \\ 61.7 & 65.0\end{array}$

61.7

Polluted water after collapsing 51.7
Hindering activ- Reduced shrimp ities of aquatic growth and animals 38.3
Natural food for shrimp, crab, fish 48.3 productivity 73.3
Supplemental feed for livestock 6.7

No impact 18.3

\section{Maintaining adequate coverage percentage of vegetation/pond area}

\begin{tabular}{|c|c|c|c|c|c|}
\hline & $15-20 \%$ & $20-30 \%$ & $30-40 \%$ & $40-50 \%$ & $50-60 \%$ \\
\hline Farmer ideas (\%) & 18.3 & 38.3 & 23.3 & 16.7 & 3.3 \\
\hline \multicolumn{6}{|c|}{ 5. Types of seaweed and aquatic plant desire to be maintained in the culture ponds } \\
\hline & Gracilaria & Enteromorpha & Cladophoraceae & Najas & Eleocharis \\
\hline Farmer ideas $(\%)$ & 46.7 & 31.7 & 11.7 & 28.3 & 26.7 \\
\hline
\end{tabular}

Farmers' opinions are consistent with the results of previous studies, seaweed and aquatic plants play important roles in brackish water bodies such as providing suitable habitat, creating abundant natural food sources, and nursery ground for larvae and reproductive ground for aquatic animals. They also absorb nutrients in the water body for their growth resulting in improvement of water quality and ecosystem balance (Hurd et al., 2014; Jaikumar et al., 2011; Vaheeda \& Thara, 2014).

Impact of seaweed and aquatic plants: the results of the interviews show that when seaweed and aquatic plants overgrow in the improved extensive shrimp pond, they can cause some adverse effects to the culture pond. For example, making pond water very clear (50.0\% of farmer), causing polluted water after dying $(51.7 \%)$, limited living space and hindered the activities of shrimp and crab (38.3\%) as a consequence reducing the growth and production of farmed shrimp (73.3\%). However, small proportion of famers $(18.3 \%)$ thought that overdevelopment of seaweed and aquatic plants were not harmful to shrimp ponds (Table 5). Similar finding was reported by Durborow et al. (2007), aquatic weed played positive roles in water bodies, but when they become excessively abundant, it caused low concentrations of dissolved oxygen at night and high 
fluctuation of pond environment. Furthermore, when they died off, it led to serious water quality problems as they released a lot of toxic gases $\left(\mathrm{H}_{2} \mathrm{~S}\right.$, $\mathrm{NH}_{3}$ ) that are harmful to shrimp and fish in the pond or can lead to mass mortalities (Durborow et al., 2007; Jaikumar et al., 2011; Thomas \& da Cunha, 2010).

Methods controlling seaweed and aquatic plants: to eliminate or reduce abundance of seaweed and aquatic plants in the improved extensive shrimp ponds, $53.3 \%$ of farmer suggested that pond preparation should be done carefully, and combined with maintaining appropriate turbidity $(35-40 \mathrm{~cm})$ and water level in the platform $(\geq 0.5 \mathrm{~m})$. The majority of farmer $(66.7 \%)$ applied partial remove of biomass when they occupied about $40-50 \%$ of the pond area, and other farmers $(56.7 \%)$ used chemicals (algaecides, BKC) to kill macroalgae. However, some farmers $(15.0 \%)$ stated that they did not control macroalgae development in their ponds as red seaweed (Gracilaria) and stone weed (Najas) commonly developed in their ponds, these macroalgae did not adversely affect to the culture pond (Table 5).

Durborow et al. (2007) reported that management of aquatic weeds in aquaculture ponds with environmentally friendly and cost-effective approach depends on the type of weed, the extent of weed coverage, the species and life-stage of fish or crustaceans in the pond, water quality, time of year, and weather. Understanding the interaction of these factors requires practical experience to apply optimal procedures for controlling the overgrowth of aquatic weeds in the pond. Chemical measure was the fastest way to eradicate weeds, however, chemical weed control was risky because water quality of the pond deteriorated when large biomass of weeds were killed. Therefore, prevention of weeds is the best method to manage aquatic plants. In addition, authors suggested that control excessive growth of aquatic weeds should combine various procedures (physical and biological measures); chemical measure was recommended only applying in pond preparation.

Maintaining appropriate vegetation coverage: results showed that $38.3 \%$ of farmers preferred to maintain vegetation coverage about $20-30 \%$ of the pond area, others desired to sustain the coverage of $30-40 \%$ (23.3\% farmers), or $10-20 \%$ coverage (18.3\% of farmer) and $40-50 \%$ coverage $(16.7 \%$ of farmer). Few farmers (3.3\%) wanted to keep 50$60 \%$ vegetation coverage in the culture ponds (Table 5). Farmers' opinions in the present study are similar to recent survey (Anh et al., 2017; Son et al., 2018).

Types of seaweed and aquatic plants desire to be maintained in the culture ponds: among the seaweeds and aquatic plants occurred in ponds, red seaweed (Gracilaria) was most preferred by farmers (46.7\%) follow by gut weed Enteromorpha (31.7\%), stone weed Najas (28.3\%), tube-grass Eleocharis $(26.7 \%)$, and only $11.7 \%$ farmers want to maintain green seaweed Cladophoraceae in their ponds (Table 5).

Similarly, in a survey of the ITB-Vietnam project (2011) in the MD, it was reported that seaweeds (Enteromorpha, Gracilaria) and aquatic plants (Najas, Eleocharis) naturally developed in the improved extensive shrimp ponds that function as natural food sources for shrimp, crab and fish source, improve water quality in the pond, contributing to enhancing productivity and income for farmers. Particularly, green macroalgae Cladophoraceae develop quickly, and it is difficult to control their overgrowth (Anh et al., 2017), so very few farmers prefer to maintain it in their ponds. Red seaweed Gracilaria is economically important as a major source of agar, human food, traditional medicine and animal feed (Peng et al., 2009). This alga also has high biofiltration capabilities that can improve the production and economic efficiency of aquaculture via integrated aquaculture systems (Yang et al., 2015; Ihsan, et al., 2019). For these reasons, many farmers prefer to maintain red seaweed Gracilaria in shrimp ponds.

\section{CONCLUSIONS}

Seaweeds and aquatic plants play an important role in improving the water quality, providing direct food and shelter, and providing natural food sources for shrimp, fish, and crabs in improved extensive shrimp ponds. When they overgrow, however, they cause some problems such as very clear water, water pollution when they die, and decreased shrimp growth and productivity.

The improved extensive shrimp ponds with red seaweed Gracialria dominating other seaweeds and aquatic plants (mixed vegetation) produced more shrimp (268.8 kg/ha/year) and profit (58.4 million $\mathrm{VND} /$ ha/year) than ponds with only mixed vegetation (shrimp yield of $203.1 \mathrm{~kg} / \mathrm{ha} /$ year and profit of $43.0 \mathrm{million} / \mathrm{ha} / \mathrm{year}$ ). Notably, the pond that was maintained with vegetation coverage $\leq 50 \%$ achieved higher shrimp production and profit than pond with coverage $>50 \%$. 
Research on biology and cultivation of red seaweed Gracilaria in the improved extensive shrimp ponds are needed to provide scientific and practical basis for the development and application of native seaweed species in the Mekong Delta.

\section{ACKNOWLEDGMENTS}

This study belongs to the Vietnamese ODA F-2 project "Green technology innovation for aquaculture", which is sponsored by the Can Tho University Improvement Project VN14-p6, supported by a Japanese ODA loan. The authors are grateful to Dang Trung Doan, Hong Van Do and Nguyen Chi Khanh for their assistance during the survey.

\section{REFERENCES}

Anh, N. T. N. (2015). Abundance and occurrence of typical green seaweeds and aquatic plants from brackish water bodies in Bac Lieu and Soc Trang provinces. Science and Technology Journal of Agriculture \& Rural Development, 15, 67-73 (in Vietnamese).

Anh, N. T. N., Hong, D. T., \& Hai, T. N. (2017). Investigating abundance and impact of green seaweed (Cladophoraceae) in the improved extensive farms from Bac Lieu and Ca Mau provinces. Scientific Journal of Can Tho University, 51B, 95-105 (in Vietnamese). DOI: 10.22144/ctu.jvn.2017.084

Brennan, D., Clayton, H., \& Be, T. T. (2000). Economic characteristics of extensive shrimp farms in the Mekong Delta. Aquaculture Economics \& Management, 4(3-4), 127-139. DOI:10.1080/13657300009380265

Hai, T. N., Minh, T. H., Phu, T. Q., \& Phuong, N. T. (2016). Shrimp industry in Vietnam. In C. Liao, N. H. Chao, \& E. M. Leano (Eds). Progress of shrimp and prawn aquaculture in the world (pp. 181-204). National Taiwan Ocean University, Keelung Taiwan, The Fisheries Society, Manila, Philippines, and Word Aquaculture Society, Louisiana, USA.

Hurd, C., Harrison, P., Bischof, K., \& Lobban, C. (2014). Physico-chemical factors as environmental stressors in seaweed biology. In Seaweed ecology and physiology (pp. 294-348). Cambridge University Press. DOI:10.1017/CBO9781139192637.008

Ihsan, Y. N., Subiyanto, G., Tri, D. K., \& Schulz, C. (2019). Nitrogen assimilation potential of seaweed (Gracilaria verrucosa) in polyculture with Pacific white shrimp (Penaeus vannamei). AACL Bioflux, 12(1), 51-62.

ITB-Vietnam. (2011). Study on distribution and culture of seaweeds and aquatic plants in the Mekong delta, Vietnam. Phase 2. International co-operation plan. Algen Sustainable \& Center Novem, Netherland.

Jaikumar, M., Chellaiyan, D., Kanagu, L., Kumar, P. S., \& Stella, C. (2011). Distribution and succession of aquatic macrophytes in Chilka Lake - India. Journal of Ecology and the Natural Environment, 3(16), 499-508.
Mai, L. T. P., Son, V. N., Ni, D. V., \& Hai, T. N. (2016). Evaluation of impacts and solutions to deal with the climate change in the improved extensive culture system in the Mekong Delta. Scientific Journal of Can Tho University, 42A, 28-39 (in Vietnamese).

Ministry of Agriculture and Rural Development. (2017). Mekong Delta: Shrimp farming adapt to drought, saline intrusion. https://www.fistenet.gov.vn/VietNamFisheries/doc-tin/008104/2017-06-06/001.

Nhuong, T. V., Luu, L. T, Tu, T. Q., Tam, P. M., \& Nguyet, T. T. A. (2002). Vietnam shrimp farming review. Individual partner report for the project: Policy research for sustainable shrimp farming in Asia. European Commission INCO-DEV Project PORESSFA No.IC4-2001-10042, CEMARE University of Portsmouth UK and RIA1, Bac Ninh, Vietnam, 19 p.

O’Hare, M. T., Baattrup-Pedersen, A., Baumgarte, I., Freeman, A., Gunn, I.D.M., Lázár, A. N., Sinclair, R., Andrew J. Wade, A. J., \& Bowes, M. J. (2018). Responses of aquatic plants to eutrophication in rivers: A revised conceptual model. Frontier in Plant Science, 9(451), 1-13. DOI:10.3389/fpls.2018.00451

Peng, C., Hong-Bo, S., Di, X., \& Song, Q. (2009). Progress in Gracilaria biology and developmental utilization: main issues and prospective. Reviews in Fisheries Science, 17(4), 494-504. DOI: 10.1080/10641260903144586

Son, V. N., Nhan, B. V., Hai, T. N., \& Phuong, N. T. (2018). Evaluation of technical and financial efficiency of tiger shrimp culture in improved extensive and shrimp - rices ystems in Thoi Binh dictrict- $\mathrm{Ca}$ Mau province. Scientific Journal of Can Tho University, 54(3B), 164-176 (in Vietnamese). DOI: 10.22144/ctu.jvn.2018.053

Tho, N., Merckx, R., \& Ut, V. N. (2012). Biological characteristics of the improved extensive shrimp system in the Mekong delta of Vietnam. Aquaculture Research, 43(4), 526-537. DOI: 10.1111/j.13652109.2011.02858.x

Thakur, M.C., Reddy, C. R. K., \& Bhavanath, J. (2008). Seasonal variation in biomass and species composition of seaweeds stranded along Port Okha, northwest coast of India. Journal of Earth System Science, 117(3), 211218. DOI: $10.1007 / \mathrm{s} 12040-008-0025-\mathrm{y}$

Thomas, S. M., \& da Cunha, E. R. (2010). The role of macrophytes in habitat structuring in aquatic ecosystems: methods of measurement, causes and consequences on animal assemblages' composition and biodiversity. Acta Limnologica Brasiliensia, 22(2), 218-236. DOI: 10.4322/actalb.02202011

Vaheeda, K. K., \& Thara, K. S. (2014). Aquatic and semi aquatic macrophytic flora of brackish waters of Kodungallur, Thrissur Dist, Kerala. Annals of Plant Sciences, 3(06), 748-751.

Yang, Y., Chai, Z., Wang, Q., Chen, W., He, Z., \& Jiang, S. (2015). Cultivation of seaweed Gracilaria in Chinese coastal waters and its contribution to environmental improvements. Algal Research, 9, 236-244. DOI: 10.1016/j.algal.2015.03.017. 